\title{
ACCOUNTING CONSERVATISM AND BOARD CHARACTERISTICS: PORTUGUESE EVIDENCE
}

\author{
Sandra Alves* \\ School of Accountancy and Administration, University of Aveiro
}

\begin{abstract}
For a sample of 26 non-financial listed Portuguese firms-year from 2002 to 2016, this study extends previous research by empirically examining how board structure affects the magnitude of accounting conservatism for companies listed in Portugal. Mainly, we focus on the main characteristics of the board structure that are highlighted by the Portuguese Securities Market Supervisory Authority's recommendations: board size, board composition, board's monitoring committees and number of board meeting. This study predicts and finds a non-linear relationship between board size and conservatism. Specifically, we find that as board size increases up to 8 members, the sample firms employ more conservatism, consistent with the idea that smaller boards can be more effective than larger boards in monitoring managerial behaviour. When board size reaches beyond 8 members, a negative relationship between board size and conservatism accounting occurs. We also find that both boards comprised of more non-executive members and high board meetings frequency lead firms to report more conservatively.
\end{abstract}

Keywords: Board Structure, Conservatism Accounting, CMVM's recommendations.

Received: 8 October 2019

Accepted: 27 September 2021

https://doi.org/10.33736/ijbs.4305.2021

\section{INTRODUCTION}

Boards of directors are an important internal control mechanism designed to monitor the actions of top management. Boards of directors are also responsible for monitoring the quality of the information contained in financial reports. In this vein, Portuguese company law establishes that the boards of directors have the responsibility to monitor the firm's accounting system and the financial statements.

It is considered that, mainly, the board size, the board composition, the number of board meeting, the structure and composition of the board's monitoring committees are important characteristics that affect the usefulness of the board in monitoring management (Fama, 1980; Fama \& Jensen, 1983; Jensen, 1993; Loderer \& Peyer, 2002; Vafeas, 1999; Xie et al., 2003).

Conservatism is considered an effective mechanism to address agency problem (Watts, 2003). Accounting conservatism understates earnings and net assets, and consequently it reduces the ability of managers to engage in activities that will benefit themselves. Conservatism is also

\footnotetext{
- Corresponding author: School of Accountancy and Administration, University of Aveiro, R. Associação Humanitária dos Bombeiros Voluntários de Aveiro, 3810-500 Aveiro, Portugal; Telephone: +351234380110; Email: sandra.alves@ua.pt
} 
considered a potentially useful tool for directors in realising their role of ratifying and monitoring key decisions (Ahmed \& Duellman, 2007; Caskey \& Laux, 2017). In fact, Watts (2003) argues that the board of directors is interested in conservatism, because conservatism can restrict managers' tendency to over-compensate themselves by using aggressive accounting, or reporting good news more than bad news. Caskey and Laux (2017) point out that the board of directors prefers conservative accounting because it helps the board to prevent investments with a high likelihood of failure. Consequently, studying the relationship between board characteristics and conservatism is potentially interesting.

The Portuguese Securities Market Supervisory Authority [Comissão de Mercado de Valores Mobiliários, henceforth "CMVM"] has adopted the recommendations that board members must be of a plural nature, that the board of directors should include a sufficient number of non-executive directors, that the board of directors should create internal control committees and disclosure the number of meetings held by the board of directors. These recommendations suggest that the Portuguese stock market regulator, in line with the literature on boards of directors, also concurs that board size, board composition, board's monitoring committees, number of board meetings are effective corporate governance techniques.

Consequently, board of directors and its structure appear to be an effective corporate governance mechanism to decrease agency problems. Several research studies have found that board structure have an impact on corporate financial reporting, including conservatism accounting (Ahmed \& Duellman, 2007; Beekes et al., 2004; Dechow et al., 1996; García-Sánchez, Martínez-Ferrero \& García-Meca, 2017; Peasnell et al., 2005). For example, Dimitropoulos and Asteriou (2010) document that companies with a higher proportion of non-executive directors on the board are more conservative in reporting bad news. Ahmed and Henry (2012) find evidence that voluntary audit committee formation, increasing board independence and decreasing board size are positively associated with unconditional accounting conservatism and negatively related to the degree of conditional conservatism.

This study extends previous research by empirically examining how board structure affects the magnitude of accounting conservatism for companies listed in Portugal. Specifically, we focus on the main characteristics of the board structure that are highlighted by the 2013 CMVM's corporate governance code (recommendations) [henceforth "CMVM's recommendations"]: board size, board composition, board's monitoring committees and number of board meeting. Therefore, this study identifies the characteristics of the board structure that may affect conservatism accounting practices in Portugal and thus the financial reporting integrity.

The main contribution of the current study is that in contrast to similar studies, this does not assume that the two views on how board size associates with firms' conservative accounting practices are mutually exclusive. To our knowledge, this is the first study estimating the potential non-linear relationship between board size and earnings conservatism. This study shows that board size is a positive for firms up to a certain point; however, after that further benefits do not arise for shareholders. It might be interesting for further research to investigate what the optimal average board size is for the highest earnings quality. The results of this study are useful for composing a board of directors. It also contributes to the literature by extending the research into the effects of board structure on conservatism accounting beyond the US and the UK environments (e.g. Elshandidy \& Hassanein, 2014; García Lara et al., 2007; Jeong \& Kim, 2013). Furthermore, this 
paper represents the first known study examining the association between board structure and conservatism accounting in Portugal, where the majority of the Portuguese listed firms use the Latin corporate governance model. In addition, while the ownership in the US and in the UK listed firms is widely diffused, the ownership in Portuguese listed firms is highly concentrated. Thus, Portuguese boards operate in a unique jurisdiction where public equity markets are highly concentrated. Since high ownership concentration is a norm rather than an exception around the world, our study of the Portuguese boards should be of general interest. In addition, this study investigates the role of governance in conservatism accounting in a civil-law settings, as a Portugal, which differ from the common-law countries in terms of corporate governance and accounting practices. There are others significant differences between Portuguese publicly traded firms and those of Anglo-Saxon economies, which is what the majority of studies focus on. The firm's market size is too distinct, since the number of publicly traded firms in the markets is also different. In terms of liquidity, the differences are also relevant. For instance, only 20 companies are more liquid and are present in the Portuguese index, compared to 500 of the Standard \& Poor and 100 of Nasdaq. These features can affect the board effectiveness to monitor managers' accounting choices. Therefore, these differences make it relevant to analyse Portugal, not only to expand international evidence, but also to compare the results and to determine whether the conclusions are international evidence. This paper also contributes to the debate of how a board of directors should be composed. For instance, firms with high aggressive accounting (less conservative) and a low proportion of non-executive directors on their board that want to higher their earnings quality, may consider a higher proportion of non-executive directors, since this will lead to more monitoring on management and increase the quality of financial reporting information that is communicated to the public. Finally, our findings can provide useful information for investors, regulators and managers since they have implications for all these related parties. Financial statement information is the main path managers use in order to communicate significant information to investors. If this information is reported in a conservative manner it enables market participants to evaluate a firm's future accounting earnings and equity, especially in firms with highly concentrated equity ownership.

Using two proxies for accounting conservatism: a market-value based proxy and an accrual-based proxy, the results support the predicted non-linear relationship between board size and conservatism accounting for a sample of 26 non-financial listed Portuguese firms-years from 2002 to 2016. We also find that both boards comprised of more non-executive members and high board meetings frequency lead firms to report more conservatively. Overall, our findings suggest that smaller boards with higher proportions of non-executive directors and a greater number of meeting tend to be more conservative.

The remainder of the paper is organized as follows. In section two, we give a brief overview of the CMVM recommendations for board structures. The literature review and the development of testable hypotheses are presented in section three. Section four describes the variable measurement and research design, while section five reports the main results and the results of sensitivity analysis. Section six summarises and concludes this paper. 


\section{CMVM RECOMMENDATIONS FOR BOARD STRUCTURES}

In relation to the structure and role of the board of directors the CMVM's recommendations incorporate eight recommendations. The first recommendation considers that board members must be of a plural nature and the board itself must carry out an effective guidance in the management of the company, their directors and managers. In addition, the board of directors should include a sufficient number of non-executive directors, whose role is to continuously monitor and assess the management of the company by the executive members of the board. The second recommendation establishes that the non-executive members of the board of directors must include a sufficient number of independent members. When there is only one non-executive director, he/she must also be independent. The third recommendation determines the board of directors should create internal control committees, with the power to assess the corporate structure and its governance. The fourth recommendation establishes that the remuneration of members of the board of directors should be structured in such a way as to permit the interests of board members to be in line with those of the company, and should be disclosed annually in individual terms. The fifth recommendation establishes that the members of the remuneration committee or equivalent should be independent as regards the members of the board of directors. The sixth recommendation determines that a proposal should be submitted to the general meeting with regard to the approval of plans for the allotment of shares, and/or options to purchase shares or based on variations in share prices, to members of the board of directors and/or employees. The seven recommendation determines the publication of the number of meetings held by the board of directors. Finally, the eight recommendation establishes that companies shall disclose the information about the professional qualifications of the members of the board of directors (CMVM, 2013).

These recommendations suggest that CMVM regulator concurs mainly that board size, board composition, board's monitoring committees and number of board meetings are important characteristics that affect the effectiveness of the board in monitoring management.

\section{LITERATURE REVIEW AND TESTABLE HYPOTHESES}

The function of the board of directors is to monitor and discipline a firm's management, thereby ensuring that managers pursue the interests of shareholders (Jensen \& Meckling, 1976). Thus, given that the role of the board of director is to monitor manager behaviour and accounting conservatism is considered an effective mechanism to address agency problem as well as a potentially useful tool for directors in realising their role of ratifying and monitoring key decisions (Ahmed \& Duellman, 2007; Caskey \& Laux, 2017; , 2003), it is important to understand the link between board structure and accounting conservatism. An effective board is likely to demand that managers adopt conservative accounting practices to prevent overcompensation, to reduce litigation risks and to reduce the probability and magnitude of corporate collapses. Thus, based on previous research on the association between board structure and accounting conservatism, and considering the specificities of the Portuguese context, in this section we develop the hypotheses that are tested in the empirical analysis. We focus on the main characteristics of the board structure that are highlighted by the CMVM's recommendations: board size, board composition, board's monitoring committees and number of board meetings. 


\subsection{Board size and conservatism accounting}

Board size can affect boards' functions and potentially firm performance (Jensen, 1993). There are two competing views in the literature about the effects of board size. One view is that the higher the number of members on the board, the greater the monitoring activity of management (Xie et al., 2003). Moreover, "a larger board could bring together specialists from various functional areas and therefore contribute to higher firm value" (Loderer \& Peyer, 2002, p. 182), suggesting that large boards allow directors to specialize. Greater specialization can lead to more effective monitoring (Ahmed \& Duellman, 2007). Thus, managers in companies with a good board size will be disciplined to supply high-quality earnings information. Really, if a large board size is a signal of board effectiveness, then the higher the number of members on the board, the lower should be the likelihood of managers to use aggressive (more conservative) accounting. Ahmed and Henry (2012), Jeong and Kim (2013), Elshandidy and Hassanein (2014) and Sultana (2015) find a significant positive association between conservatism accounting and board size.

A competing view is that a larger board would introduce problems of communication and coordination, as well as of decision-making (Jensen, 1993). Large boards can be controlled more easily by managers, which reduce the monitoring efficiency of the boards. Therefore, if a large board size is a signal of board ineffectiveness, then the higher the number of members on the board, the higher should be the likelihood of managers to use aggressive (less conservative) accounting. For example, Suleiman (2014), Boussaid et al. (2015) and Nasr and Ntim (2018) find that firms with a bigger board size have a less demand for conservative accounting.

Taking the above opposing arguments into account, we predict a non-linear relationship between board size and conservatism accounting. Our prediction is based on the assumption that board members are an important internal control mechanism to monitor the actions of management and that board size affects the roles of the boards. We expect that the monitoring function is likely to improve in a small board. That is, in a smaller board each board member will be more probable to take personal responsibility for the board's monitoring of the financial statements, and consequently to monitor manager's activity. In addition, as Vafeas (1999), we expect that in a small board, directors have more opportunities to discuss accounting in detail. In contrast, we expect that the monitoring function is likely to decrease in a large board. That is, as board size increases, it may become difficult after a certain point (optimal size) for boards to monitor managerial behaviour and, consequently, to limit aggressive accounting. In larger boards the responsibility of monitoring management is diffused, leading to great dilution on each member personally, which can reduce the quality of accounting scrutiny. In addition, larger boards can create coordination and communication problems, which may result in poor monitoring. Therefore, neither argument by itself is likely to satisfactorily explain the relationship between board size and conservatism accounting. Thus, we propose a "U" shaped relationship between board size and conservatism accounting, with an optimal board size existing midway. Below this optimal or the most efficient size, there is a positive relationship between board size and conservatism accounting followed by a negative relationship. So, we test the following hypothesis:

\section{H1: Board size positively influences the conservatism accounting at smaller sizes} followed by a negative influence at larger sizes. 


\subsection{Board composition and conservatism accounting}

Fama (1980) and Fama and Jensen (1983) suggest that the effectiveness of the board is a function of the composition of the board. Non-executive directors (NEDs), because of their independence and specialised expertise, are considered as a particularly powerful monitoring device of executive directors' actions (Rediker \& Seth, 1995; Chen, 2015). NEDs are potentially effective since "outside directors have incentives to develop reputations as experts in decision control" (Fama \& Jensen, 1983, p. 315). Thus, it is expected that a strong board of directors understands the benefits of conservatism and, consequently, requires more conservative accounting. In this vein, Beekes et al. (2004), Ahmed and Duellman (2007), García Lara et al. (2007), Dimitropoulos and Asteriou (2010), Elshandidy and Hassanein (2014), Suleiman (2014), Majeed et al. (2017) and Nasr and Ntim (2018) find a positive relationship between non-executive directors and accounting conservatism.

CMVM's recommendations also suggest the inclusion of non-executive directors on the board for the supervision, control and evaluation of executive directors. Therefore, given the empirical evidence and CMVM's recommendation, we test the following hypothesis:

\section{H2: The proportion of non-executive directors on the board is positively related to conservatism accounting.}

\subsection{Board's monitoring and conservatism accounting}

Boards of directors improve their performance by delegating authority to standing committees, that specialize in narrowly defined functions (Klein, 1998). The CMVM's regulation, also, recommends the creation of internal control committees with the power to assess the corporate structure and its governance. Among the specific committees that can be created within boards of directors, the audit committee has been considered as having a very important role within the governance structure. The main role of the audit committee is to oversee the financial reporting process and ensure high-quality and transparency of financial reporting and corporate accountability (Xie et al., 2003).

Thus, it is expected that audit committees encourage conservative accounting approaches resulting in reliable accounting information. In addition, Sultana (2015, p. 90) refers that "as the adoption of conservative accounting practices is likely to attract less criticism than aggressive accounting practices, audit committee members are therefore likely to favour accounting conservatism to enhance reputational capital and future board appointment opportunities". Ahmed and Henry (2012) and Wistawan et al. (2015) find that the existence of an audit committee is related to more conservative accounting. Sultana (2015) finds that audit committees (with financial experts, experienced members and meet more frequently) exhibit higher level of conservatism.

Based on CMVM's recommendation and previous research our third hypothesis is the following:

\section{H3: The existence of an audit committee is positively related to conservatism accounting.}




\subsection{Board meetings and conservatism accounting}

Board meetings are a necessary and legal part of board governance. There is no set number of meetings that the CMVM's recommendation proposes, but is states that the board of directors should meet regularly and annual reports should disclosure the number of meetings held a year. Board meetings are considered an important resource which improves the effectiveness of the board and firm value (Brick \& Chidambaran, 2010; Firth et al., 2007; Jensen, 1993; Vafeas, 1999). Consequently, boards who meet more frequently are more likely to perform their duties in accordance with shareholders' interests. Also, high board meeting frequency may allow directors to assign more time to discuss the financial reporting process. Thus, high board meeting frequency will be positively associated with accounting conservatism. For example, Boussaid et al. (2015) find that high board meeting frequency lead to more conservatism accounting.

Overall, more frequent board meetings mean that boards have more opportunity to scrutinize management decisions and more time to discuss the financial reporting process, which is expected to result in higher accounting conservatism in financial reporting. Thus, we test the following hypothesis:

H4: Board meetings are positively related to conservatism accounting.

\section{VARIABLE MEASUREMENT AND RESEARCH DESIGN}

\subsection{Measuring board structure}

As referred previously, to analyse whether a firm's board structure affects the level of conservatism accounting, we focus on the main characteristics of the board structure that are highlighted by the CMVM's recommendations: board size, board composition, board's monitoring committees and number of board meetings. Board size (Bsize) is the number of members on the board. Board composition (Bcomp) is calculated by dividing the number of non-executive directors by the total number of board members. Audit committee (Audit) is measured as an indicator variable taking the value of 1 when the firm has an audit committee and 0 otherwise. Board Meetings (Meetings) is the number of annual boards of director meetings.

\subsection{Measuring conservatism accounting}

We employ two proxies for accounting conservatism: a market-value based proxy and an accrualbased proxy.

Following previous studies (e.g., Ahmed et al., 2002; Beaver \& Ryan, 2000; Givoly \& Hayn, 2000), the market-value based measure of conservatism, CONS-MTB, is the market-to-book ratio. "Intuitively, conservative accounting results in reducing book values relative to market values" (Ahmed \& Duellman, 2011, p. 616). Moreover, market-to-book ratio captures the cumulative effects of conservatism since the inception of the firm (Ahmed et al., 2002; Ahmed \& Duellman, $2007,2011)$. Thus, a key advantage of this measure is its cumulative nature.

In line with Givoly and Hayn (2000), Ahmed and Duellman (2007), Sun and Liu (2011) and Ahmed and Henry (2012) the accrual-based measure of conservatism, CONS-ACC, is income operations 
plus depreciation less cash flows from operations deflated by average total assets, multiplied by negative one. According to Givoly and Hayn (2000), the intuition underlying this measure is that conservative accounting results in persistently negative accruals.

\subsection{Control variables}

Several control variables are introduced to isolate other relevant variables that may influence the level of conservatism accounting. Previous studies suggest that firm size (Size), leverage (Leverage) and profitability (Profit) are associated with conservatism accounting (Ahmed et al., 2002; Ahmed \& Henry, 2012; García Lara et al., 2009; Sun \& Lin, 2011). Additionally, as the ownership in Portuguese listed firms is highly concentrated, we also include the ownership concentration (Concentration) variable to control for the potential effect of ownership concentration on conservatism accounting.

\subsection{Regression model}

This study predicts a non-linear relationship between board size and conservatism accounting. Following a quadratic function specification, Bsize and $B s i z e^{2}$ (the square value of Bsize) are introduced to capture the predicted non-linear relationship. To improve the reliability of the findings, we evaluate the association between board structure and accounting conservatism by estimating the following regression by the three different statistical approaches in panel data (pooled ordinary least squares (OLS), fixed effects and random effects method):

$$
\begin{gathered}
\text { Conservatism }_{i t}=\beta_{0}+\beta_{1}\left(\text { Bsize }_{i t}\right)+\beta_{2}\left(\text { Bsize }^{2}{ }_{i t}\right)+\beta_{3}\left(\text { Bcomp }_{i t}\right)+\beta_{4}\left(\text { Audit }_{i t}\right) \\
+\beta_{5}\left(\text { Meetings }_{i t}\right)+\beta_{6}\left(\text { Size }_{i t}\right)+\beta_{7}\left(\text { Leverage }_{i t}\right)+\beta_{8}\left(\text { Profit }_{i t}\right) \\
+\beta_{9}\left(\text { Concentration }_{i t}\right)+\varepsilon_{i t}
\end{gathered}
$$

Where:

Conservatism $_{i t}=$ one of two measures of conservatism for firm i for period $\mathrm{t}$ : CONS_MTB, the market-value-based conservatism proxy, defined as the market-to-book ratio.

CONS_ACC, the accrual-based measure of conservatism, defined as the income operations plus depreciation less cash flows from operations deflated by average total assets, multiplied by negative one.

$B s_{i z} e_{i t}=$ number of members on the board of firm $\mathrm{i}$ for period $\mathrm{t}$.

$B s i z e^{2}{ }_{i t}=$ squared of the number of members on the board of firm i for period $\mathrm{t}$.

$B c o m p i t=$ ratio between the number of non-executive directors and the total number of board members of firm i for period $t$.

Audit $_{i t}=$ dummy variable: 1 if the firm $\mathrm{i}$ for period t has an audit committee and 0 otherwise. Meetings $s_{i t}=$ number of annual boards of director meetings of firm $\mathrm{i}$ for period $\mathrm{t}$.

Size $_{i t}=\operatorname{logarithm}$ of market value of equity of firm i for period $\mathrm{t}$.

Leverage $_{i t}=$ ratio between the book value of all liabilities and the total assets of firm i for period t.

Profit $_{i t}=$ return on equity ratio of firm i for period $\mathrm{t}$. 
Concentration $_{i t}=$ proportion of stocks owned by shareholders who own at least $2 \%$ of the common stock of firm i for period $\mathrm{t}$.

$\varepsilon_{\text {it }}=$ residual term of firm i for period t.

$\beta_{0}$ is a constant, $\beta_{1}$ to $\beta_{9}$ are the coefficients.

\subsection{Sample selection}

The initial sample includes all companies (749 firm-year observations in total) whose stocks are listed in the main market, Euronext Lisbon, for the period 2002-2016. Foreign companies (49 in total) are excluded. Football club companies (11 in total) are excluded, too. Companies not having shares listed in the previous year and companies whose shares were delisted in the following year are also excluded (220 in total). Companies (10 in total) with missing data are also excluded. Financial companies (69 in total) are excluded, too. As a result, the final sample size is 26 nonfinancial companies per year and, thus, 390 observations in total. This reduced number of observations may influence some results. Nevertheless, this limitation is an immediate consequence of the small size of the Portuguese stock market.

Data to measure the variables are collected from the Annual Report and Corporate Governance Report. Both Annual Report and Corporate Governance Report are available on-line at www.cmvm.pt. We obtain stock price data from the Euronext Lisbon, which allows measuring the variable firm size.

\section{RESULTS AND DISCUSSION}

\subsection{Descriptive statistics}

Table 1 presents the sample descriptive statistics for the explanatory variables used in this research.

Table 1: Summary of Descriptive Statistics

\begin{tabular}{|c|c|c|c|c|}
\hline & Mean & Median & Min. & Max. \\
\hline CONS_MTB & 1.211 & 0.851 & -12.980 & 28.256 \\
\hline CONS ACC & 0.083 & 0.064 & -0.662 & 0.980 \\
\hline Bsize & 8.250 & 8.000 & 3.000 & 23.000 \\
\hline Bcomp & 0.414 & 0.461 & 0.000 & 0.888 \\
\hline Audit & 0.360 & 1.000 & 0.000 & 1.000 \\
\hline Meetings & 13.580 & 11.000 & 2.000 & 84.000 \\
\hline Size & 19.910 & 18.743 & 12.429 & 23.517 \\
\hline Leverage & 0.775 & 0.729 & 0.062 & 4.148 \\
\hline Profit & 0.120 & 0.075 & -5.148 & 27.932 \\
\hline Concentration & 0.734 & 0.769 & 0.085 & 0.988 \\
\hline
\end{tabular}

Notes: $C O N S \_M T B$ is the market-to-book ratio; $C O N S \_A C C$ represents the income operations plus depreciation less cash flows from operations deflated by average total assets, multiplied by negative one; Bsize is the number of members of the board; Bcomp represents the ratio between the number of non-executive directors and the total number of board members; Audit dummy variable which takes a value 1 if the firm has an audit committee and 0 otherwise; Meetings is the number of annual boards of director meetings; Size represents the firm's size; Leverage represents the ratio between the book value of 
all liabilities and the total assets; Profit is the return on equity ratio; Concentration represents the proportion of stocks owned by shareholders who own at least $2 \%$ of the common stock.

Table 1 shows that, while CONS_MTB, ranges between about -12.98 and 28.256 , the mean and median are about 1.211 and 0.851 . The mean (median) CONS_ACC is $0.083(0.064)$, with a minimum of -0.662 and a maximum of 0.980 . Bsize is comprised of approximately 8 members (with a median of 8 members). About $41.4 \%$ (with a median of $46.1 \%$ ) of the members of the board are non-executive directors. The analysis of Table 1 also shows that about $36 \%$ of companies have an audit committee (Audit). The mean (median) number of annual board meetings is approximately 14 (11). No firm had less than two meeting per year and the maximum number of times the board is 84. Therefore, descriptive statistics for the Bsize, Bcomp, Audit and Meetings variables suggest that Portuguese listed firms have a wide variety of board structures and compositions.

In relation to the control variables, Table 1 shows that the mean of firm size (Size) is about EUR 980 million with a minimum of EUR 250 thousand and a maximum of EUR 16.345 million. Leverage variable represents on average 0.775 of the total assets of the company. Table 1 shows that, while Profit, ranges between about -5.148 and 27.932, the mean is about 0.120. The Concentration variable shows that Portuguese listed companies display a large degree of ownership concentration.

\subsection{Regression results}

Table 2 presents three estimation methods, for the equation 1, in the panel data statistics: the pooled OLS, the fixed effects and the random effects method.

Table 2: Regressions Results

\begin{tabular}{|c|c|c|c|c|c|c|}
\hline \multirow{2}{*}{$\begin{array}{c}\text { Dependent } \\
\text { variable } \\
\end{array}$} & \multicolumn{3}{|c|}{ CONS_MTB } & \multicolumn{3}{|c|}{ CONS_ACC } \\
\hline & Pooled & Fixed Effect & Random Effect & Pooled & Fixed Effect & Random Effect \\
\hline $\begin{array}{c}\begin{array}{c}\text { Independent } \\
\text { variables }\end{array} \\
\end{array}$ & $\begin{array}{l}\text { Coefficient } \\
\text { (t-Statistic) }\end{array}$ & $\begin{array}{l}\text { Coefficient } \\
\text { (t-Statistic) }\end{array}$ & $\begin{array}{l}\text { Coefficient } \\
\text { (z-Statistic) }\end{array}$ & $\begin{array}{l}\text { Coefficient } \\
\text { (t-Statistic) }\end{array}$ & $\begin{array}{l}\text { Coefficient } \\
\text { (t-Statistic) }\end{array}$ & $\begin{array}{l}\text { Coefficient } \\
(z-\text {-Statistic })\end{array}$ \\
\hline Constant & $\begin{array}{c}-0.564 \\
(-2.815)\end{array}$ & $\begin{array}{c}0.001 \\
(0.744)\end{array}$ & $\begin{array}{c}0.013 \\
(0.173)\end{array}$ & $\begin{array}{c}-0.196 \\
(-1.321)\end{array}$ & $\begin{array}{c}0.015 \\
(0.824)\end{array}$ & $\begin{array}{c}0.028 \\
(0.609)\end{array}$ \\
\hline Bsize & $\begin{array}{c}0.927 \\
(5.279) * * *\end{array}$ & $\begin{array}{c}0.602 \\
(7.380)^{* * *}\end{array}$ & $\begin{array}{c}0.378 \\
(2.072) * * *\end{array}$ & $\begin{array}{c}0.109 \\
(3.173)^{* * *}\end{array}$ & $\begin{array}{c}0.087 \\
(1.984) * *\end{array}$ & $\begin{array}{c}0.205 \\
(2.230) * *\end{array}$ \\
\hline Bsize $^{2}$ & $\begin{array}{c}-0.057 \\
(-3.497) * *\end{array}$ & $\begin{array}{l}-0.082 \\
(-1.675)^{*}\end{array}$ & $\begin{array}{c}-0.023 \\
(-2.888) * * *\end{array}$ & $\begin{array}{l}-0.007 \\
(-1.769)^{*}\end{array}$ & $\begin{array}{c}-0.229 \\
(-2.202)^{* * *}\end{array}$ & $\begin{array}{c}-0.013 \\
(-2.565) * *\end{array}$ \\
\hline Bcomp & $\begin{array}{c}0.981 \\
(6.305)^{* * * *}\end{array}$ & $\begin{array}{c}0.396 \\
(6.535)^{* * * *}\end{array}$ & $\begin{array}{c}0.142 \\
(2.270)^{* *}\end{array}$ & $\begin{array}{c}0.178 \\
(2.975)^{* *}\end{array}$ & $\begin{array}{c}0.135 \\
(2.378)^{* *}\end{array}$ & $\begin{array}{c}0.571 \\
(3.653)^{* * * *}\end{array}$ \\
\hline Audit & $\begin{array}{c}0.002 \\
(0.507)\end{array}$ & $\begin{array}{c}0.001 \\
(0.744)\end{array}$ & $\begin{array}{l}0.073 \\
(1.871)^{*}\end{array}$ & $\begin{array}{c}0.048 \\
(0.344)\end{array}$ & $\begin{array}{c}0.007 \\
(0.706)\end{array}$ & $\begin{array}{l}-0.081 \\
(-1.495)\end{array}$ \\
\hline Meetings & $\begin{array}{c}0.058 \\
(2.677)^{* *}\end{array}$ & $\begin{array}{c}0.004 \\
(2.829) * * *\end{array}$ & $\begin{array}{c}0.049 \\
(2.230)^{* *}\end{array}$ & $\begin{array}{c}0.057 \\
(3.043)^{* *}\end{array}$ & $\begin{array}{c}0.071 \\
(0.859)\end{array}$ & $\begin{array}{c}0.057 \\
(1.813) *\end{array}$ \\
\hline Size & $\begin{array}{c}0.802 \\
(4.891)^{* * * *}\end{array}$ & $\begin{array}{c}0.141 \\
(3.074)^{* * * *}\end{array}$ & $\begin{array}{c}0.216 \\
(3.958)^{* * * *}\end{array}$ & $\begin{array}{c}0.081 \\
(6.901)^{* * * *}\end{array}$ & $\begin{array}{c}0.162 \\
(2.709)^{* * * *}\end{array}$ & $\begin{array}{c}0.176 \\
(4.021)^{* * *}\end{array}$ \\
\hline Leverage & $\begin{array}{c}0.012 \\
(1.972)^{*}\end{array}$ & $\begin{array}{c}-0.082 \\
(-1.675) *\end{array}$ & $\begin{array}{c}0.084 \\
(2.037)^{* *}\end{array}$ & $\begin{array}{c}0.099 \\
(5.502)^{* *}\end{array}$ & $\begin{array}{c}0.038 \\
(1.877)^{*}\end{array}$ & $\begin{array}{c}0.058 \\
(1.813)^{*}\end{array}$ \\
\hline Profit & $\begin{array}{c}-0.072 \\
(-0.944)\end{array}$ & $\begin{array}{l}-1.071 \\
(-1.378)\end{array}$ & $\begin{array}{c}0.305 \\
(2.017)^{* *}\end{array}$ & $\begin{array}{l}-0.058 \\
(-0.301)\end{array}$ & $\begin{array}{l}0.001 \\
0.054)\end{array}$ & $\begin{array}{c}0.381 \\
(1.934) *\end{array}$ \\
\hline Concentration & $\begin{array}{c}0.704 \\
(5.101)^{* *}\end{array}$ & $\begin{array}{c}0.257 \\
(2.208)^{* *}\end{array}$ & $\begin{array}{c}0.148 \\
(2.754)^{* * * *}\end{array}$ & $\begin{array}{c}0.353 \\
(1.989)^{*}\end{array}$ & $\begin{array}{c}0.222 \\
(1.757)^{*}\end{array}$ & $\begin{array}{c}0.128 \\
(2.157)^{* *}\end{array}$ \\
\hline $\begin{array}{l}\text { R-squared } \\
\text { Adjusted R-squared }\end{array}$ & $\begin{array}{l}18.8 \% \\
16.9 \%\end{array}$ & $\begin{array}{l}- \\
-\end{array}$ & $\begin{array}{l}- \\
-\end{array}$ & $\begin{array}{l}14.3 \% \\
12.2 \%\end{array}$ & $\begin{array}{l}- \\
-\end{array}$ & $\begin{array}{l}- \\
-\end{array}$ \\
\hline
\end{tabular}




\begin{tabular}{l|c|c|c|c|c|c} 
Within R-squared & - & $36.9 \%$ & - & - & $32.1 \%$ & - \\
F-statistic & $9.787 * * *$ & $30.377 * * *$ & - & $7.024 * * *$ & $28.938 * * *$ & - \\
Rho & - & - & 0.604 & - & - & 0.547 \\
Durbin-Watson & - & - & 2.103 & - & - & 2.095 \\
\hline
\end{tabular}

Notes: $C O N S \_M T B$ is the market-to-book ratio; $C O N S \_A C C$ represents the income operations plus depreciation less cash flows from operations deflated by average total assets, multiplied by negative one; Bsize is the number of members of the board; $B s i z e^{2}$ is the squared of the number of members of the board; Bcomp represents the ratio between the number of non-executive directors and the total number of board members; Audit dummy variable which takes a value 1 if the firm has an audit committee and 0 otherwise; Meetings is the number of annual boards of director meetings; Size represents the firm's size; Leverage represents the ratio between the book value of all liabilities and the total assets; Profit is the return on equity ratio; Concentration represents the proportion of stocks owned by shareholders who own at least $2 \%$ of the common stock.

*** Significant at the 1-percent level; ** Significant at the 5-percent level; * Significant at the 10-percent level.

To identify which model is appropriate, the pooled OLS model or the panel random effect model, the Breusch-Pagan test is used. This test is designed to test random effects depending on the value of the chi-squared. If the null hypothesis is not rejected, the pooled regression model is appropriate. To choose between the pooled OLS and the panel fixed effect model, the F-test is used. If the null hypothesis is rejected, the fixed effect regression model is appropriate. To determine the use of the fixed effect model or the random effect model, the Hausman test is used by calculating the p-value (Prob>chi-square). If the null hypothesis is rejected, the random effects model is not appropriate.

Results reported in table 3 indicate that the Breusch-Pagan test results favour the panel random effect over the pooled OLS estimation model. The F-test results favour the fixed effect model over the pooled OLS model. The result of the Hausman test statistics in the Table 3 suggests that the random effects model is the appropriate panel data estimator for the equation 1. Consequently, we interpret the results of random effects model.

Table 3 - Appropriate model

\begin{tabular}{lcc}
\hline Dependent variable & CONS_MTB & CONS_ACC \\
\hline & Breusch-Pagan test & \\
Chi-square & 69.204 & 66.045 \\
Prob $>$ Chi2 & 0.000 & 0.000 \\
& F-test & \\
F-statistic & 5.752 & 0.000 \\
Prob. & 7.098 & 0.000 \\
& Hausman test & \\
Chi-square & 10.134 & 13.019 \\
Prob $>$ Chi2 & 0.119 & 0.099 \\
\hline \hline
\end{tabular}

Results reported in Table 2 show a non-linear relationship between board size and conservatism accounting. Both the estimated coefficients of Bsize and Bsize $e^{2}$ are statistically significant with both $C O N S \_M T B$ and $C O N S \_A C C$ and have the expected signs. As we expected, the results indicate that smaller boards seem more effective in monitoring the financial reporting process then large boards. Given the estimated values for the Bsize and Bsize $e^{2}$ coefficients, the 'turning point' of the relation between board size and conservatism accounting is about 8 members ${ }^{1}$. This suggests

\footnotetext{
${ }^{1}$ When the Conservatism variable is CONS_MTB, the 'turning point' (maximisation point) is $\cong 8.21\left(-\beta_{1} /\left(2 * \beta_{2}\right)=-(0.378 /(2 *-\right.$ $0.023)$ ). When the Conservatism variable is CONS_ACC, the 'turning point' (maximisation point) is $\cong 7.88\left(-\beta_{1} /\left(2 * \beta_{2}\right)=-\right.$ $(0.205 /(2 *-0.013))$.
} 
that as board size increases up to 8 members, the sample firms employ more conservatism, consistent with the premise that in a smaller board each board member will be more probable to take personal responsibility for the board's monitoring of the financial statements. When board size reaches beyond 8 members, a negative relationship between board size and conservatism accounting occurs. This confirms our prediction that, in large boards may become difficult for members to monitor managerial behaviour and, consequently, to limit aggressive accounting.

In terms of the optimal size for a board of directors, this result is in line with the suggestions of Jensen (1993) and Lipton and Lorsch (1992). Jensen (1993) suggests that the maximum number of board of directors should be seven or eight and that, when boards exceeded that number, they are less likely to function effectively. Lipton and Lorsch (1992) recommend boards of eight or nine. Therefore, this finding supports the view that smaller boards are more effective monitors because they have a higher degree of membership coordination which could reduce the communication difficulties, information costs and incidence of severe free-rider problems (Jensen, 1993; Lipton \& Lorsch, 1992), which in turn gives managers lesser discretion in the use of aggressive accounting practices.

As in García Lara et al. (2007), Dimitropoulos and Asteriou (2010), Jeong and Kim (2013), Suleiman (2014), Majeed et al. (2017) and Nasr and Ntim (2018), we find a positive relationship between board composition and conservatism accounting (CONS_MTB and CONS_ACC), which indicates that having a larger percentage of non-executive directors is associated with more conservatism. It may be that when there are more non-executive directors, they are more likely to overrule managers, whether it is with their votes or by speaking up when they have objections. Further, the presence of more non-executive directors may constitute a credible threat to managers that may be enough to limit their self-serving behaviour.

The results suggest, only for the variable $C O N S \_M T B$, evidence that the existence of an audit committee directly influences the level of conservatism accounting.

The significant positive coefficients on the Meetings variable suggest that an increase on board meeting frequency lead managers to practice better accounting choices. Our finding is consistent with the view that high board meeting frequency may allow directors to assign more time to discuss the financial reporting process.

Results suggest that Portuguese board structures lead managers to adopt more conservative financial reporting policies, mainly when the board combines the following characteristics: smaller board size, a board composed of mostly non-executive directors and higher board meetings frequency. Therefore, a Portuguese board seems to play a significant role in monitoring the firm's accounting system. In conclusion, this study observes that adding more non-executive directors, increasing the number of board meetings and smaller board in a firm may improve the governance practices and, consequently, the quality of financial reporting.

Regarding the other variables, included as control variables, the findings are consistent with results from previous studies. We find that large firms, firms with higher leverage and high-profitability firms employ more conservatism (e.g., Ahmed et al., 2002; García Lara et al., 2009; Sun \& Lin; 2011). The results also suggest that conservatism accounting is significantly greater for firms with higher ownership concentration. 


\subsection{Sensitivity analyses}

To ensure the robustness of our results, we perform several sensitivity checks.

Balanced panel data is preferred over unbalanced panels because it allows an observation of the same unit in every time period and reduces the noise introduced by unit heterogeneity (Brooks, 2019). However, the unbalanced panel data increases the number of observations. Therefore, the first sensitivity analysis tests the impact of using unbalanced panel data (620 observations) on regression results. The sample includes all companies whose stocks are listed in the main market, (749 firm-year observations in total). Foreign companies (49 in total), football club companies (11 in total) and financial companies (69 in total) are excluded. As a result, 620 observations in total. The results (columns (1) and (2) of the Table 4) of the regression, using unbalanced panel data with 620 observations, has implications on Bsize $e^{2}$, Audit, Meetings, Size and Profit variables. When the dependent variable is CONS_ACC (column 2), the $B s i z e^{2}$ variable wins significance level (from $\mathrm{p}<0.05$ to $\mathrm{p}<0.01$ ). When the dependent variable is CONS_ACC (column 2), the Audit variable wins significance level. For both dependent variables (CONS_MTB and CONS_ACC) the Size variable lost significance level (from $\mathrm{p}<0.01$ to $\mathrm{p}<0.05$ ). The Profit and Meetings variables are now not significant. The other results remain unchanged.

The second sensitivity analysis tests the impact of using alternative definition for the conservatism variable on regression results. The accrual-based measure of conservatism (CONS-ACC) is estimate using the Ball and Shivakumar (2006) model. The results (column 3) of the regression, using alternative variable to measure CONS_ACC has implications on Audit variable, which is now not significant.

The next sensitivity analysis examines the effect of influential observations on results. Where outliers are found (namely in the variables CONS_MTB, Bsize, Meetings and Profit), a winserization method is used to test the robustness of the results. Extreme values (defined as values that are more than three standard deviations away from the mean) are replaced by values that are exactly three standard deviations away from the mean. The results (columns (4) and (5)) do not differ from results presented previously in Table 2 .

We also examine the effects of sales growth on conservatism variable. Sales growth may influence the market's expectations of future growth captured in Conservatism variable (Ahmed et al., 2002). The Sales Growth variable is the annual percentage change in sales. The results (columns (6) and (7) of the Table 4) of the regression, which examine the effects of sales growth on Conservatism variables, have implications on Bsize $e^{2}$ Bcomp and Profit variables. When the dependent variable is CONS_ACC (column 7), the $B s i z e^{2}$ variable wins significance level (from $\mathrm{p}<0.05$ to $\mathrm{p}<0.01$ ). When the dependent variable is CONS_MTB (column 6), the Bcomp variable wins significance level (from $\mathrm{p}<0.05$ to $\mathrm{p}<0.01$ ). When the dependent variable is CONS_ACC (column 7), the Bcomp variable wins significance level (from $\mathrm{p}<0.10$ to $\mathrm{p}<0.05$ ). The Sales Growth is not related to Conservatism. The other results remain unchanged.

Overall, the several sensitivity analyses conducted largely corroborate the results presented in Table 2. 
Table 4: Regressions Results of Sensitivity Analyses

\begin{tabular}{|c|c|c|c|c|c|c|c|}
\hline \multirow[b]{3}{*}{$\begin{array}{c}\text { Dependent } \\
\text { variable }\end{array}$} & (1) & $(2)$ & (3) & (4) & $(\mathbf{5 )}$ & (6) & $(7)$ \\
\hline & \multicolumn{2}{|c|}{ Unbalanced panel data } & $\begin{array}{c}\text { Ball \& } \\
\text { Shivakumar } \\
\text { (2006) model }\end{array}$ & \multicolumn{2}{|c|}{$\begin{array}{l}\text { Effect of influential } \\
\text { observations }\end{array}$} & \multicolumn{2}{|c|}{ Effect of sales growth } \\
\hline & CONS_MTB & CONS_ACC & CONS_ACC & CONS_MTB & CONS_ACC & CONS_MTB & CONS_ACC \\
\hline & Random Effect & Random Effect & Random Effect & Random Effect & Random Effect & Random Effect & Random Effect \\
\hline $\begin{array}{c}\begin{array}{c}\text { Independent } \\
\text { variables }\end{array} \\
\end{array}$ & \begin{tabular}{|l|}
$\begin{array}{c}\text { Coefficient } \\
(z-\text { Statistic })\end{array}$ \\
\end{tabular} & $\begin{array}{l}\begin{array}{l}\text { Coefficient } \\
(z-\text { Statistic })\end{array} \\
\end{array}$ & \begin{tabular}{|l|}
$\begin{array}{l}\text { Coefficient } \\
(z-\text { Statistic })\end{array}$ \\
\end{tabular} & $\begin{array}{l}\begin{array}{l}\text { Coefficient } \\
(z-\text {-Statistic })\end{array} \\
\end{array}$ & $\begin{array}{l}\text { Coefficient } \\
(z-\text { Statistic })\end{array}$ & \begin{tabular}{|l|}
$\begin{array}{l}\text { Coefficient } \\
(z \text {-Statistic })\end{array}$ \\
\end{tabular} & $\begin{array}{l}\text { Coefficient } \\
(z-\text { Statistic })\end{array}$ \\
\hline Constant & $\begin{array}{c}0.019 \\
(0.870)\end{array}$ & $\begin{array}{c}0.060 \\
(1.461)\end{array}$ & $\begin{array}{l}0.030 \\
(1.011)\end{array}$ & $\begin{array}{c}0.012 \\
(0.171)\end{array}$ & $\begin{array}{c}0.020 \\
(0.567)\end{array}$ & $\begin{array}{c}0.003 \\
(0.585)\end{array}$ & $\begin{array}{c}0.022 \\
(0.196)\end{array}$ \\
\hline Bsize & $\begin{array}{c}0.170 \\
(3.096) * * *\end{array}$ & $\begin{array}{c}0.152 \\
(2.973) * *\end{array}$ & $\begin{array}{c}0.133 \\
(2.257) * *\end{array}$ & $\begin{array}{c}0.378 \\
(2.070)^{* * *}\end{array}$ & $\begin{array}{c}0.215 \\
(2.233)^{* *}\end{array}$ & $\begin{array}{c}0.377 \\
(2.999) * * *\end{array}$ & $\begin{array}{c}0.245 \\
(2.287) * *\end{array}$ \\
\hline Bsize $^{2}$ & $\begin{array}{c}-0.010 \\
(-2.709) * * *\end{array}$ & $\begin{array}{c}-0.009 \\
(-2.248) * *\end{array}$ & $\begin{array}{c}-0.009 \\
(-1.985)^{* * *}\end{array}$ & $\begin{array}{c}-0.023 \\
(-2.886)^{* * *}\end{array}$ & $\begin{array}{c}-0.014 \\
(-2.567) * *\end{array}$ & $\begin{array}{c}-0.022 \\
(-2.764)^{* * *}\end{array}$ & $\begin{array}{c}-0.016 \\
(-2.704) * * *\end{array}$ \\
\hline Bcomp & $\begin{array}{c}0.072 \\
(2.178)^{* *}\end{array}$ & $\begin{array}{c}0.056 \\
(3.028)^{* * *}\end{array}$ & $\begin{array}{c}0.506 \\
(2.446) * *\end{array}$ & $\begin{array}{c}0.139 \\
(2.259)^{* *}\end{array}$ & $\begin{array}{c}0.570 \\
(3.643)^{* * *}\end{array}$ & $\begin{array}{c}0.476 \\
(3.112)^{* * * *}\end{array}$ & $\begin{array}{c}0.468 \\
(3.511)^{* * *}\end{array}$ \\
\hline Audit & $\begin{array}{c}0.282 \\
(1.842)^{*}\end{array}$ & $\begin{array}{c}0.218 \\
(1.827)^{*}\end{array}$ & $\begin{array}{c}0.015 \\
(0.829)\end{array}$ & $\begin{array}{c}0.071 \\
(1.870)^{*}\end{array}$ & $\begin{array}{c}-0.079 \\
(-1.501)\end{array}$ & $\begin{array}{c}0.213 \\
(1.678) *\end{array}$ & $\begin{array}{c}-0.056 \\
(-0.600)\end{array}$ \\
\hline Meetings & $\begin{array}{c}0.021 \\
(0.587)\end{array}$ & $\begin{array}{c}0.060 \\
(1.406)\end{array}$ & $\begin{array}{c}0.115 \\
(3.116)^{* * *}\end{array}$ & $\begin{array}{c}0.050 \\
(2.236) * *\end{array}$ & $\begin{array}{c}0.057 \\
(1.813)^{*}\end{array}$ & $\begin{array}{c}0.053 \\
(2.031)^{* *}\end{array}$ & $\begin{array}{c}0.050 \\
(1.877)^{*}\end{array}$ \\
\hline Size & $\begin{array}{c}0.087 \\
(2.343)^{* *}\end{array}$ & $\begin{array}{c}0.138 \\
(2.363)^{* * *}\end{array}$ & $\begin{array}{c}0.123 \\
(4.139) * * *\end{array}$ & $\begin{array}{c}0.214 \\
(3.952)^{* * * *}\end{array}$ & $\begin{array}{c}0.181 \\
(4.103)^{* * * *}\end{array}$ & $\begin{array}{c}0.334 \\
(2.580)^{* * * *}\end{array}$ & $\begin{array}{c}0.114 \\
(2.144)^{* * * *}\end{array}$ \\
\hline Leverage & $\begin{array}{c}0.070 \\
(2.018)^{* *}\end{array}$ & $\begin{array}{c}0.110 \\
(2.125)^{* *}\end{array}$ & $\begin{array}{c}0.020 \\
(2.982)^{* * * *}\end{array}$ & $\begin{array}{c}0.085 \\
(2.039)^{* *}\end{array}$ & $\begin{array}{l}0.051 \\
(1.809) *\end{array}$ & $\begin{array}{c}0.060 \\
(2.239)^{* *}\end{array}$ & $\begin{array}{l}0.059 \\
(1.788)^{*}\end{array}$ \\
\hline Profit & $\begin{array}{c}0.058 \\
(0.459)\end{array}$ & $\begin{array}{c}0.076 \\
(0.582)\end{array}$ & $\begin{array}{l}-0.013 \\
(-0.225)\end{array}$ & $\begin{array}{c}0.299 \\
(2.076)^{* *}\end{array}$ & $\begin{array}{c}0.379 \\
(1.936) *\end{array}$ & $\begin{array}{c}0.278 \\
(2.100)^{* *}\end{array}$ & $\begin{array}{c}0.208 \\
(2.074) * *\end{array}$ \\
\hline Concentration & $\begin{array}{c}0.119 \\
(2.735)^{* * *}\end{array}$ & $\begin{array}{c}0.100 \\
(2.115)^{* *}\end{array}$ & $\begin{array}{c}0.131 \\
(2.059) * * *\end{array}$ & $\begin{array}{c}0.132 \\
(2.756)^{* * * *}\end{array}$ & $\begin{array}{c}0.131 \\
(2.168)^{* *}\end{array}$ & $\begin{array}{c}0.220 \\
(2.791)^{* * * *}\end{array}$ & $\begin{array}{c}0.166 \\
(2.322)^{* *}\end{array}$ \\
\hline Sales Growth & $\begin{array}{l}- \\
- \\
\end{array}$ & $\begin{array}{l}- \\
- \\
\end{array}$ & $\begin{array}{l}- \\
-\end{array}$ & $\begin{array}{l}- \\
-\end{array}$ & $\begin{array}{c}- \\
- \\
\end{array}$ & $\begin{array}{c}0.028 \\
(0.806)\end{array}$ & $\begin{array}{c}0.032 \\
(0.430)\end{array}$ \\
\hline $\begin{array}{l}\text { Rho } \\
\text { Durbin-Watson }\end{array}$ & $\begin{array}{l}0.456 \\
1.914\end{array}$ & $\begin{array}{l}0.436 \\
1.863\end{array}$ & $\begin{array}{l}0.323 \\
1.359\end{array}$ & $\begin{array}{l}0.534 \\
2.215\end{array}$ & $\begin{array}{l}0.523 \\
2.194\end{array}$ & $\begin{array}{l}0.583 \\
2.436\end{array}$ & $\begin{array}{l}0.516 \\
2.156\end{array}$ \\
\hline
\end{tabular}

\section{CONCLUSION}

This study investigates whether board characteristics affect the level of accounting conservatism on Portuguese listed companies. In particular, we focus on the main characteristics of the board structure that are highlighted by the Portuguese Securities Market Supervisory Authority recommendations: board size, board composition, board's monitoring committees and board meetings frequency. We employ two proxies for accounting conservatism: a market-value based proxy and an accrual-based proxy.

Extant literature investigating the association between board size and conservatism accounting has either implicitly or explicitly assumed that these two competing views are mutually exclusive (e.g., Boussaid et al., 2015; Nasr \& Ntim, 2018). This study departs from that assumption and predicts a non-linear association between board size and conservatism accounting.

The results support the predicted non-linear relationship. The predicted positive relationship between board size and conservatism is observed within the lower region of board size. A negative relationship is found within the higher board size region. We also find that the proportion of nonexecutive directors on the board is positively associated with conservatism accounting. This is consistent with previous studies, which indicate consistently that boards comprised of more nonexecutive members will constrain aggressive accounting choices. Our finding also indicates that 
higher board meetings frequency lead firms to report more conservatively. However, results suggest no evidence that the existence of an audit committee directly influences the level of accounting conservatism. Thus, this study observes that adding more non-executive directors, increasing the number of board meetings and smaller board in a firm may lead to more conservatism, and, consequently, improve the governance practices and quality of financial reporting. Overall, our findings are consistent with results from previous studies, which find that boards of directors demand more conservative accounting to facilitate their monitoring of managers and that firms with good governance structures tend to employ more conservative accounting (Ahmed \& Duellman, 2007; García Lara et al., 2007, 2009; Majeed et al., 2017; Nasr \& Ntim, 2018; Wistawan et al., 2015).

The results also reveal that there is more conservatism accounting when firm size, leverage and ownership concentration are high.

The findings of this study make the following contributions. First, the results indicate that, on average, both board size, board composition and board meetings frequency have an impact on the levels of accounting conservatism in Portuguese listed firms. In particular, this finding suggests that a smaller board, a board composed of mostly non-executive directors and a high board meetings frequency are a positive step toward improving earnings quality. Second, the findings are relevant for countries with an institutional environment (mainly concentrated ownership) similar to that of Portugal. Third, the findings also provide useful information to investors in evaluating the impact of board structure on earnings quality, especially under concentrated ownership. Indeed, investors may wish to consider how different board structures may help them to protect their equity interests and reduce information asymmetry through accounting conservatism. Consequently, our empirical findings may be important for capital market participants since they provide additional and useful insights regarding the managerial quality of listed firms and its impact on the relevance of accounting information. Finally, the results could also be of interest to regulators, as well to supervisors, in considering regulatory reforms in order to maintain or improve the effectiveness of the board of directors. In addition, the roles of the regulators, as well of the supervisors, in protecting the financial reporting system can be assisted through a more comprehensive understanding of how board structure affects conservatism accounting, and consequently final reporting quality in the company.

\section{REFERENCES}

Ahmed, A. S., Billings, B. K., Morton, R. M., \& Stanford-Harris, M. (2002). The role of accounting conservatism in mitigating bondholder-shareholder conflicts over dividend policy and in reducing debt costs. The Accounting Review, 77(4), 867-890.

Ahmed, A. S., \& Duellman, S. (2007). Accounting conservatism and board of director characteristics: An empirical analysis. Journal of Accounting and Economics, 46(2/3), 411-437.

Ahmed, A. S., \& Duellman, S. (2011). Evidence on the role of accounting conservatism in monitoring managers' investment decisions. Accounting \& Finance, 51(3), 609-633.

Ahmed, K., \& Henry, D. (2012). Accounting conservatism and voluntary corporate governance mechanisms by Australian firms. Accounting and Finance, 52, 631-662. 
Ball, R., \& Shivakumar, L. (2006). The role of accruals in asymmetrically timely gain and loss recognition. Journal of Accounting Research, 44(2), 207-42.

Beaver, W., \& Ryan, S. (2000). Biases and lags in book value and their effects on the ability of the book-to-market ratio to predict book return on equity. Journal of Accounting Research, 38(1), 127-148.

Beekes, W., Pope, P., \& Young, S. (2004). The link between earnings timeliness, earnings conservatism and board composition: evidence from the UK. Corporate Governance: An International Review, 12(1), 47-59.

Boussaid, N., Hamza, T., \& Sougné, D. (2015). Corporate Board Attributes and Conditional Accounting Conservatism: Evidence from French Firms. The Journal of Applied Business Research, 31(3), 871-889.

Brick, I. E., \& Chidambaran, N. K. (2010). Board meetings, committee structure and firm value. Journal of Corporate Finance, 16(4), 533-553.

Brooks, C. (2019). Introductory Econometrics for Finance ( ${ }^{\text {th }}$ ed). Cambridge University Press.

Caskey, J., \& Laux, V. (2017). Corporate Governance, Accounting Conservatism, and Manipulation. Management Science, 63(2), 424-437.

Chen, T. (2015). Institutions, board structure, and corporate performance: Evidence from Chinese firms. Journal of Corporate Finance, 32, 217-237.

CMVM. (2013). Corporate Governance Code (Recommendations). http://www.cmvm.pt/

Dechow, P. M., Sloan, R. G. \& Sweeney, A. P. (1996). Causes and consequences of earnings manipulations: An analysis of firms subject to enforcement actions by the SEC. Contemporary Accounting Research, 13, 1-36.

Dimitropoulos, P. E. \& Asteriou, D. (2010). The effect of board composition on the informativeness and quality of annual earnings: Empirical evidence from Greece. Research in International Business and Finance, 24, 190-205.

Elshandidy, T., \& Hassanein, A. (2014). Do IFRS and board of directors' independence affect accounting conservatism? Applied Financial Economics, 24(16), 1091-1102.

Fama, E. F. (1980). Agency Problems and the Theory of the Firm. Journal of Political Economy, 88(2), 288-307.

Fama, E. F., \& Jensen, M. C. (1983). Separation of Ownership and Control. The Journal of Law and Economics, 2(26), 301-325.

Firth, M., Fung, P. M. Y., \& Rui, O. M. (2007). Ownership, two-tier board structure, and the informativeness of earnings - Evidence from China. Journal of Accounting and Public Policy, 26(4), 463-496.

García Lara, J. M., García Osma, B., \& Penalva, F. (2007). Board of Directors' Characteristics and Conditional Accounting Conservatism: Spanish Evidence. European Accounting Review, 16(4), 727-755.

García Lara, J. M., García Osma, B., \& Penalva, F. (2009). Accounting conservatism and corporate governance. Review of Accounting Studies, 14, 161-201.

Givoly, D., \& Hayn, C. (2000). The changing time-series properties of earnings, cash flows and accruals: Has financial reporting become more conservative?. Journal of Accounting and Economics, 29(3), 287-320.

Jensen, M. C. (1993). The Modern Industrial Revolution, Exit, and the Failure of Internal Control Systems. The Journal of Finance, 3(48), 831-880.

Jensen, M. C., \& Meckling, W. H. (1976). Theory of the Firm: Managerial Behavior, Agency and Ownership Structure. Journal of Financial Economics, 4(3), 305-360. 
Jeong, K., \& Kim, H. (2013). Equity-Based Compensation to Outside Directors and Accounting Conservatism. The Journal of Applied Business Research, 29(3), 885-900.

Klein, A. (1998). Firm performance and board committee structure. Journal of Law and Economics, 41, 275-303.

Lipton, M., \& Lorsch, J. W. (1992). A Modest Proposal for Improved Corporate Governance. The Business Lawyer, 48(1), 59-77.

Loderer, C., \& Peyer, U. (2002). Board Overlap, Seat Accumulation and Share Prices. European Financial Management, 8(2), 165-192.

Majeed, M. A., Zhang, X.-Z., \& Wang, Z. (2017). Product market competition, regulatory changes, ownership structure, and accounting conservatism. Chinese Management Studies, 11(4), 658-688.

Nasr, M. A., \& Ntim, C. G. (2018). Corporate governance mechanisms and accounting conservatism: evidence from Egypt. Corporate Governance: The International Journal of Business in Society, 18(3), 386-407.

Peasnell, K. V., Pope, P. F., \& Young, S. (2005). Board monitoring and earnings management: Do outside directors influence abnormal accruals?. Journal of Business Finance \& Accounting, 32(7-8), 1311-1346.

Rediker, K. J., \& Seth, A. (1995). Boards of directors and substitution effects of alternative governance mechanisms. Strategic Governance Journal, 16(2), 85-99.

Suleiman, S. (2014). Corporate Governance Mechanisms and Accounting Conservatism. Journal of Management Policies and Practices, 2(2), 113-127.

Sultana, N. (2015). Audit Committee Characteristics and Accounting Conservatism. International Journal of Auditing, 19(2), 88-102.

Sun, J., \& Liu, G. (2011). The effect of analyst coverage on accounting conservatism. Managerial Finance, 37(1), 5-20.

Vafeas, N. (1999). Board Meeting Frequency and Firm Performance. Journal of Financial Economics, 53(1), 113-142.

Watts, R. L. (2003). Conservatism in accounting part I: Explanations and Implications. Accounting Horizons, 17(3), 207-221.

Wistawan, M. A. P., Subroto, B., \& Ghofar, A. (2015). The Characteristics Board of Directors, Family Ownership and Accounting Conservatism: Evidence from Family Public Firms in Indonesia. Research Journal of Finance and Accounting, 6(22), 113-121.

Xie, B., Davidson, W. N., \& DaDalt, P. J. (2003). Earnings management and corporate governance: the role of the board and the audit committee. Journal of Corporate Finance, 9, 295-316. 